\title{
SCHOLARSHIP ON INDONESIA AND RAISON D'ETAT: PERSONAL EXPERIENCE
}

\section{Benedict R. O'G. Anderson}

\section{Prefatory Note}

In the fall of 1985, I was invited to a small conference in Washington on the topic of the relations between scholars and governments. One purpose of the meeting was to have attendees compare personal experiences. Accordingly, I prepared the document appended below. At the time I had no thought of publishing it. But now that a decade has passed since its composition, and three decades since the opening of the chain of events that it describes, the text may have a certain historical value, since, although seen from my personal perspective, it covers in some detail the difficult relationships between the Cornell Modern Indonesia Project and sections of the governments of the United States and Indonesia over a good part of the New Order period. I have not tried to update the document except by way of a few explanatory footnotes. I have, however, lightly edited it, since it was originally designed for an audience that knew little about Indonesia.

On October 1, 1965, what at first sight seemed a coup d'état occurred in Jakarta, in the course of which six influential generals were murdered by junior officers and troops of the Tjakrabirawa Regiment, President Sukarno's palace guard. Later the same day, a successful countermovement, led by then Maj. Gen. Suharto, took place. Claiming that the original "coup" had been masterminded by the Indonesian Communist Party (PKI), Suharto and his political allies then launched a systematic assault on the party, its affiliated organizations, and its sympathizers. Between mid-October 1965 and mid-January 1966, Army-directed massacres claimed somewhere between five hundred thousand and one million lives. Hundreds of thousands of other people were imprisoned and many of these were also tortured. 
Dissatisfied with the Army leadership's claims as to what had really happened before and on October 1, 1965, three researchers at the Cornell Modern Indonesia Project-Ruth McVey, Frederick Bunnell, and I (the latter two then still graduate students)-tried to reconstruct a more plausible account on the basis of the unique documentary resources of the Cornell University Library's Echols Collection on Southeast Asia. By January 10, 1966, we had completed a 162-page text, entitled "A Preliminary Analysis of the October 1, 1965 Coup in Indonesia," which seriously questioned the view that the Communists had masterminded the coup, suggesting instead that the evidence pointed to severe intra-Army conflicts as the most likely cause. We then circulated the text, for comment and criticism, to a very small number academic colleagues, but also, on a personal basis, to two American government officials: namely, William Bundy, Assistant Secretary of State for Far Eastern Affairs, and Howard Federspiel, Indonesian desk officer at the Department of State. In a covering letter we wrote that if they wished to make use of any of our text's material in their own writings, they should feel free to do so, but that they should make no mention of the source. The reason for this caution was that massacres and jailings were still going on, and we feared that if the Indonesian Army leadership knew of what we had done, reprisals might be taken against any or all Indonesians who had ever studied at Cornell, or who were known to be personal friends of ours.

These precautions quickly proved futile, partly because of our own political innocence, in part also, it must be said, on account of the (for that period) solidity of our data and analysis. On January 27, 1966, Professor George Kahin, Director of the Cornell Modern Indonesia Project, testified before the US House of Representatives' Subcommittee on East Asian and Pacific Affairs, then headed by Representative Clement Zablocki. Without mentioning our text, he nonetheless expressed skepticism of Indonesian Army claims that the "coup" had been supported by Peking, and ascribed its likely origin to intra-Army tensions. In the course of the following month, Kahin also arranged for Ruth McVey to give a briefing on the "coup" to columnist Joseph Kraft. On March 3, to our collective consternation, Kraft published a column in the Washington Post which summarized the main conclusions of our "Preliminary Analysis," and referred to it explicitly as a "paper" prepared by a group of scholars at Cornell. From this point on the "Preliminary Analysis" began acquiring notoriety as the "Cornell Paper." As a result of Kraft's column, the public became aware of our study, and very soon thereafter a surreptitiously made photostat of it (apparently reproduced from one of the two copies sent to the State Department) was transmitted to the military authorities in Jakarta.

Around the same time, a number of newspaper and academic articles began to appear which, whatever their difference in tone and perspective, were nonetheless based heavily on the evidence we had accumulated. All the authors were among the original recipients of the document. On February 19, 1966, Professor W. F. Wertheim published an article on the "coup" in the liberal Dutch weekly, De Groene Amsterdammer. Professor Daniel Lev, a Cornell Ph.D. then teaching at the university of California at Berkeley, published "Indonesia 1965: The Year of the Coup," in the February 1966 issue of Asian Survey. In early March, Professor Philippe Devillers wrote an article for the Parisian weekly Le Nouvel Observateur. Next 'Lucien Rey' (nom de plume of an English intellectual in hiding for evading the draft during Britain's repression in Cyprus) published "Dossier of the Indonesian Drama" in the March- 
April 1966 issue of the New Left Review, edited by my brother Perry Anderson. Professor Herbert Feith, a Cornell Ph.D. teaching at Monash university in Australia, wrote an article on Indonesia's political prisoners for the May 30, 1966 issue of Current Affairs Bulletin; and my co-author Frederick Bunnell published "Indonesia's QuasiMilitary Regime" in the January 1967 issue of Current History. None of these articles was solicited by us, and all but one of the authors were then, or later became, Southeast Asian scholars of indisputable integrity and standing. At the same time, it is understandable that with the "Cornell Paper" in their hands, Indonesia's Army leaders were quick to imagine behind all these articles a sort of international, but Cornellbased, conspiracy ${ }^{1}$; for them the stakes were very high-for if our analysis were even partly correct, the enormous bloodshed they had engineered could not possibly be justified as punishment for a murderous Communist plot.

The initial counter to the "Cornell Paper" in Jakarta took the form of books and articles supporting the Army viewpoint: for example, Arthur Dommen's "The Attempted Coup in Indonesia" in the January-March 1966 issue of The China Quarterly; Professor Justus M. van der Kroef's "Gestapu in Indonesia," in the summer 1966 issue of Orbis and John Sutter's “Two Faces of Konfrontasi: 'Crush Malaysia' and the Gestapu" in the October 1966 number of Asian Survey. Then in 1967 historian, Nugroho Notosusanto and Lieutenant-Colonel Ismail Saleh spent some time at The Rand Corporation in Santa Monica working closely with Dr. Guy Pauker, an Indonesian specialist long known for his intimate ties with the Indonesian military. Nugroho then held the titular rank of colonel in the Indonesian Army as head of the Armed Forces' Historical Center, and at the end of December 1965 had hastily published a book called 40 Hari Kegagalan "G. 30. S." (The Forty Day Failure of the September 30th Movement). Ismail Saleh was a rising star in the Judge Advocate's Department and had been deeply involved in the work of the extraordinary military tribunals (Mahmilub) set up early in 1966 to try those accused of involvement in the coup. The three men drafted a tripartite book in English which eventually was published in Jakarta in 1968 as The Coup Attempt of the 'September 30 Movement' in Indonesia, though, for unexplained reasons, Pauker's name and the section he wrote had meantime been deleted. Finally, in 1969, the journalist Arnold Brackman published The Communist Collapse in Indonesia, which not only supported Army claims but singled out the "Cornell Paper" and its authors for extremely hostile criticism. At the same time, the government in Jakarta (and the press it controlled) was cautious in criticizing us, most likely because it expected that it could soon bring us around to its point of view. In the fall of 1966, Ruslan Abdulgani, a leading figure in the conservative wing of the Indonesian Nationalist Party, and then head of Indonesia's Mission to the UN, visited Cornell and spoke with us at length about his deep concern.

Meanwhile, I myself was absorbed in completing my dissertation on the Indonesian Revolution, which was successfully defended in March 1967. I had planned to visit Indonesia immediately afterwards in order to gather additional materials on both the

\footnotetext{
${ }^{1}$ An indication of how seriously the Indonesian military took the "Cornell Paper" was accidentally discovered by George Kahin on May 8, 1967, when he was wandering through the Ministry of Defense building in Jakarta, looking for Nugroho Notosusanto. In the process, Kahin came upon a large auditorium where lectures had just been held. An enormous blackboard behind the lectern was filled with a diagram, in the center of which was written "The Cornell Paper." From this center, arrows radiated to the names of the above-mentioned articles and a few more with which he was not familiar.
} 
Revolution and the "coup." Accordingly, I started the process of requesting a visa from the Indonesian Embassy in Washington, but encountered evasion and footdragging. (From an American Embassy document dated June 30, 1967, which turned up many years later in the papers of former US Ambassador to Indonesia Howard P. Jones, it is clear that, on his return to Indonesia, Abdulgani urged the Army and the "visa community" in Jakarta to deny me a visa if I applied, and that this recommendation was approved.) Blocked in Washington, I went to London in April 1967, and managed to secure a friendly interview with Lt. Gen. Ibrahim Adjie, a rival of President Suharto who had been shunted off to be the Indonesian Ambassador to the Court of St. James. He then gave me the visa I required. (If the US Embassy document is to be believed, he did this "in violation" of a directive of Indonesia's Department of Foreign Affairs.) It may be of some interest that the Embassy document made it quite clear that the US Embassy illegally intercepted correspondence between an Indonesian friend and myself prior to my arrival in Jakarta in mid-May, and between myself and Ruth McVey thereafter. The American document described Ruth McVey as "long an apologist for the PKI (Communist Party)" and myself as being "regarded, rightly or wrongly, by several informed Indonesians with whom we have talked, as an outright Communist or at least a fellow-traveler." I mention this document mainly to underline the fact that the "Cornell Paper" angered certain officials in the US government at least as much as the Indonesian Army leaders.

While in Indonesia during the summer of 1967, I encountered no real difficulties. I had useful interviews with Brig. Gen. Soesatyo, head of the Army Historical Center in Bandung, as well as with a group of officers attached to Teperpu (Central Investigating Team), which had conducted the interrogations of top "coup" suspects, to Kopkamtib (the powerful "post-coup" Command for the Restoration of Security and Order), and to the Extraordinary Military Tribunals. Among them was Col. Ali Said (later Chief Justice), who at that time had just made a certain name for himself as the presiding judge at the trial of former Foreign Minister Dr. Subandrio. I was even permitted, along with Herbert Feith, to attend the trial of Sudisman, the top surviving PKI leader, in July 1967 , and was present in court when he was sentenced to death.

In May I had been joined in Jakarta by George Kahin. Together we drew up a list of documents (of whose existence we were certain, but which had not been made public) which we believed would be essential for any full, scholarly analysis of the "coup." In separate meetings with Col. Thaher, head of Teperpu, Nugroho Notosusanto, and Judge-Advocate General Brig. Gen. Kabul Arifin, who was in overall charge of the Extraordinary Military Tribunals, Kahin presented this list. All three officials promised that they would shortly be made available to us, but by the time we left Indonesia at the end of that summer, none had materialized. ${ }^{2}$ On December 19, 1967 Kahin wrote to Thaher and Kabul Arifin, reminding them of their promise-but nothing came of these letters either.

\footnotetext{
${ }^{2}$ On May 9, 1967, the day after Kahin had called on him to request these documents, Nugroho held a press conference. There, in an apparent effort to undercut the credibility of the "Cornell Paper," he falsely asserted that Kahin had just "denounced" it as a "sarcastic and childish" effort that had been prepared "without his permission." The next day, the Jakarta press dutifully printed Nugroho's assertion. When Kahin confronted him over this brazen fabrication, Nugroho acknowledged that his statement was untrue and apologized, but refused to make a public retraction.
} 
In the spring and summer of 1968 I made a further research trip to Indonesia, trying to follow up on leads developed the previous summer. Once again, I experienced no real difficulties, though the promised documents remained as elusive as ever. The only faintly ominous note was struck by Guy Pauker of the Rand Corporation, who in an interview published in the Bandung newspaper, Pikiran Rakjat, on February 29, 1968 denounced certain unnamed Western scholars who, although they had "actually attended the Mahmilub sessions in person, continue to hold that these sessions are simply 'show trials." Such people, he believed, had "an irrational sympathy for communism in developing countries." Feith and I being the only "Western scholars" who had ever attended Mahmilub sessions, Indonesian readers had no difficulty recognizing who the "irrational sympathizers with communism in developing countries" were. It should be noted here that in the wake of the 1965-66 massacres, not only had the PKI been proscribed, but communism was legally prohibited, and all Marxist publications banned in Indonesia.

Over the course of the next two years (1969-1970), copies of a number of stenographic transcripts of various Mahmilub trials did finally come into our hands by indirect means. Perusal of these documents, and other newly gathered data, convinced us that while elements in our original analysis of early 1966 were clearly incorrect or incomplete, its overall thrust had not been disproved; and, in addition, these data made all the clearer the fact that the original Army claims were logically and evidentially untenable. There was thus no way that we could "recant" in the way that the authorities in Jakarta expected, or hoped, we eventually would do. In the meantime, we had become increasingly concerned by the selective, often highly tendentious ways, in which the "Cornell Paper" was being quoted from or alluded to, most particularly in Brackman's polemical book.

To clear the air and to enable the public to judge the "Cornell Paper" for what it was, the Cornell Modern Indonesia Project decided in 1971 to publish the text in its original form, together with a brief preface by Kahin, and an introduction by myself, which described the circumstances under which the text had originally been prepared and circulated, and detailed what we regarded, now five years later, as its main weaknesses and strengths. Prior to actual publication, Kahin had spoken to the new Judge-Advocate General, Brigadier-General Kanter, offering to include alongside the "Cornell Paper" an official Army version of the "coup." It should here be noted that in 1971 no official Army version had been published, though it was credibly reported that one had secretly been prepared under the sponsorship of General Sumitro, then Deputy Commander of Kopkamtib and the "strong man" of the Ministry of Defense. At first Kanter appeared interested, but a few weeks later backed out, probably because his superiors had, for internal political reasons, decided not to make public the Army chronicle. (To this date, twenty years after October 1965, there is still no official published version. ${ }^{3}$ ) Accordingly, the "Cornell Paper" was duly published, on its own.

That same year (1971), I received a grant from the Social Science Research Council

\footnotetext{
3 In 1994, Gerakan 30 September: Pemberontakan Partai Komunis Indonesia was published by The State Secretariat in Jakarta as the final "White Paper"-almost thirty years after the events it describes. It contains a mere 173 pages of narrative and fifty-five pages of appendices. Not least among its curious features is the absence of any named author or authors.
} 
to do research on Guided Democracy in Indonesia-i.e., on President Sukarno's six years of authoritarian rule immediately prior to the October I, 1965 "coup." In accordance with existing government regulations, I forwarded my research proposal, with the necessary documents attached, to the Indonesian Academy of Sciences (LIPI), requesting their endorsement. Thanks to LIPI's support, I was able to obtain on November 22, 1971 a five-week visitor's visa from the Indonesian Embassy in Washington. On February 17, I flew in to Jakarta from the Philippines, and on March 2 obtained an official letter of credentials from LIPI, as well as the necessary supplemental documents from the police. On March 6, the Immigration Service extended my visa until July 23,1972 . Virtually coinciding with my arrival, however, the weekly magazine Chas, widely known to be the mouthpiece of Bakin, Indonesia's powerful Intelligence Coordinating Agency, published a vitriolic front-page attack on the "Cornellians" under the headline rubric: "Cornell Scholars: Useful [to Communists] Idiots." Written by an anonymous Chas correspondent in the US, the article accused all those who had published articles based on the data in the "Cornell Paper" of spreading subversive propaganda, poisoning young Indonesian minds with New Left dogmas, and defending the Indonesian Communist Party. It asserted that the writings of these "cowardly would-be Robin Hoods" were being warmly welcomed by PKI remnants overseas and by the international communist movement in general. (In fact, since the "Cornell Paper" theorized that the PKI had been more or less duped into marginal participation in the "coup," it had, unsurprisingly, been received with resounding silence in the above-mentioned circles!).

On March 10, four days after obtaining the extension of my visa, I was abruptly summoned by the head of the Police Department's Bureau for the Supervision of Foreigners to answer questions about my proposed research. On arrival, all my police documents were withdrawn, and I was told that I was "temporarily" forbidden to carry out research. (This order was hardly necessary, since a clause in the then standard LIPI letter of credentials for foreign scholars provided that the letter was invalid without supporting police documents.) I was also told not to leave the city pending a further decision in my case. In addition, the Bureau Chief asked me to show him copies of any recent work I had done. I was able to present him with my just published book, Java in a Time of Revolution, as well as Culture and Politics in Indonesia (edited by the recently deceased Claire Holt), which included a long essay of mine on the Javanese concept of power. No information was vouchsafed as to why I was being treated in this way; I was simply told to present myself again in three weeks time.

During the following three weeks, I was very careful to follow police instructions faithfully, doing little more than borrowing books from libraries and reading them at my lodgings. But in the third week of March, Chas returned to the attack, this time against me personally. Its front-page headlines ran: "Benedict R. O'G. Anderson, His Fate Will Be Like Adamson! Pro-PKI Political Guerrillas Exploit Academic Work! The Cornell Paper Proved to Falsify History!" (I'm afraid that to this day the identity of "Adamson" continues to elude me.) The article itself attacked me for staining the scholarly name of Cornell, for infantile New Left sympathies, for spreading subversive propaganda, and so forth. The final paragraph expressed particular indignation that on March 2 (i.e., before my first summons by the police) I had had the audacity to drop 'secretly' by Chas's offices and ask to read its recent issues. Only after I left the reading room had my true identity been discovered — doubtless from the visitors' book 
where I had signed my name.

Given the fact that Chas's backer was Bakin, I should probably not have been surprised to learn, when I presented myself once again to the Head of the Bureau for the Supervision of Foreigners, that an irreversible decision had meantime been taken to bar me permanently from any further research. I could travel to consult with any of my students currently doing fieldwork in Indonesia and I could visit public libraries if I wished, but that would be all. The Bureau Head, a courtly, silver-haired Mandailing Batak, who was polite enough to say he had read my writings with interest, hinted strongly that he was not happy with the decision in my case, but that orders had come down to him from someone very high up, outside the Police Department.

At this point, I turned for help to Col. George Benson, then serving as Special Assistant to US Ambassador Francis Galbraith. Benson was then a legendary figure in Jakarta. He had served as military attache in Jakarta during the PRRI-Permesta regional rebellion of 1958-59, and had earned the trust of Army leaders for his strong support for them at a time when the CIA was known to be financing and arming the rebels. He was widely believed to be the American most intimate with and bestinformed about the Indonesian military. All three of the authors of the "Cornell Paper" had interviewed him in Washington in 1966, and Kahin had subsequently invited him to come and give a lecture at Cornell. While completely disagreeing with our analysis, he had been friendly and helpful with information. It so happened that I had gone to interview Benson ten days earlier, on March 22 (curiously enough our conversation was interrupted by a telephone call from Guy Pauker, who had just arrived from the United States).

Benson arranged for him and me to have lunch on April 4 with an old friend of his in Army intelligence, a certain Colonel Sugondo. Sugondo was apparently regarded as the Army's top expert on Communism, and had helped plan the organization of Kopkamtib, as well as working closely with Colonel Thaher at Teperpu. In the course of the lunch, he insisted that although Thaher "hated my guts," he had said nothing to the police; he was also sure that Kopkamtib was not involved. Benson commented that he had checked with Maj. Gen. Kharis Suhud, former military attache in Washington and at that time head of G-I in the Ministry of Defense, but Suhud also claimed no knowledge of my case. Though the atmosphere at the lunch was rather tense, Sugondo finally agreed to see what he could do to reverse the ban on my doing research, and promised to telephone me in a few days. At that point I was quite optimistic that eventually everything would be all right.

Then on the morning of April 6, a messenger arrived at my lodgings with a sealed envelope from the Immigration Department. When the maid came to the back of the house to tell me about the envelope, I guessed that it contained an order for my deportation. I therefore stayed out of sight and asked an Indonesian staying in the same house to pretend I was out and sign for the letter in my place. The envelope proved to contain an urgent summons for interrogation at the Security (Identification) Section of Immigration Headquarters. My Indonesian friend turned out to have acquaintances there, so he offered to go to find out what was happening, explaining that I was out of town-he had no idea where. He returned an hour later to say that as soon as he mentioned my name his acquaintances fell silent, saying only that my case was "extremely grave" and they could do nothing to help. He was instructed to find 
me as quickly as possible and bring me to Immigration HQ with my passport. If I did not report in within three days, a second summons would be issued; if that was ignored, I would face immediate arrest. I telephoned Benson at the Embassy and he urged me strongly not to go to Immigration because they would feel bound to "throw the book at me." Once things were in black and white, no reversal would be possibletoo much face would be lost. He told me to get out of town for a few days to give him time to work, and call him at home each night for news. Before dawn on Friday, April 7, I left Jakarta on my motorcycle, and traveled about the small towns of West Java for three days. On Sunday night, Benson told me over the telephone that he had checked with Sugondo, who convincingly claimed no knowledge of the Immigration Department's demarche, and later with Col. Nichlany, Deputy Chief of Bakin, whose denials were somewhat less forceful. On the other hand, Benson added, Nichlany appeared to have confused me with columnist Jack Anderson, so perhaps my adversary was not Bakin after all. By the end Nichlany and Benson had agreed that I should return to Jakarta on Monday and everything would probably be settled. I arrived back Monday evening to find an angry second summons from Immigration awaiting me. When I telephoned Benson that night, he told me he needed more time, and that I should appear at Immigration the next day twenty minutes before closing time, without my passport. I should say I did not realize I was supposed to bring it. I followed his advice and had an unpleasant stand-off with Immigration on Tuesday afternoon. They told me I must return with the passport at nine a.m. the following morning. When I spoke to Benson that night, he said he had seen Nichlany again, and Nichlany had again assured him that everything would be all right, and that my original visa status would be restored. I went to bed feeling much relieved.

When I arrived at Immigration on Wednesday morning (April 12), I was stunned to learn from the officials there that they had received instructions two weeks previously to deport me. I now had forty-eight hours to leave the country. After two hours of pleading, I finally got them to agree to stretch the forty-eight hours to five days, but I was forbidden to leave Jakarta, and I must bring round my filled-out air ticket immediately. Thereupon they stamped my visa "cancelled." The die was now cast. I therefore asked Benson if he could arrange a bargain whereby I would promise to leave promptly and without fuss, but would be given two weeks to wind up my affairs and (given the probability that it would be a very long time before I returned to Indonesia) to visit my old friends in the interior of Java. This time Benson was successful, I believe with the support of Ambassador Galbraith. I was able to visit my old friends and did leave on the exact date (April 30) to which I was committed.

On my return to Ithaca, I learned indirectly that I would henceforth be blacklisted for entry into Indonesia until I made a public disavowal of the "Cornell Paper" and agreed to the Army's claims about the coup. I was also told that the blacklist included the names of both Herbert Feith and Daniel Lev. The only thing left was to write a detailed formal letter of protest to Maj. Gen. Dr. Sjarif Thajeb, then Indonesian Ambassador in Washington, which I did on June 8. On June 28 I received a polite, but coolly evasive, reply. Soon afterwards, sale of Culture and Politics in Indonesia was banned by the authorities in Jakarta.

It was then not at all clear who exactly was responsible for my expulsion. Benson told me he felt certain that someone had brought the Chas articles to the attention of 
either General Panggabean (then Minister of Defense), General Sumitro (Deputy Head of Kopkamtib) or Lt. Gen. Sutopo Juwono (Head of Bakin), and he/they had responded angrily with a deportation order. Others pointed to Nichlany or Maj. Gen. Kharis Suhud, head of G-1, who had been military attache in Washington in 1967-70. If the report was true that he had been berated by his superiors for ineffective handling of the repercussions of the "Cornell Paper," he would have had personal reasons for wishing to settle scores.

For the next two years everything remained unchanged. Then on January 14-15, 1974, severe riots broke out in Jakarta during the state visit of Japanese Premier Kakuei Tanaka. The riots had been preceded by severe conflicts among some of President Suharto's top subordinates, and it is generally accepted that one group used agents provocateurs to organize looting and arson for its own Machiavellian purposes. In any event, in the aftermath, General Sumitro was forced to resign from the Army, General Sutopo Juwono was sent abroad to be Ambassador in The Hague, Nichlany came to Washington as Defense Attache, and Suhud lost control of G-1. Thus most of the main dramatis personae in the storm over the "Cornell Paper" fell from power, and were replaced by their adversaries.

The new power group was led by Maj. Gen. Ali Murtopo, Suharto's intelligence chief at the time of the October I, 1965 "coup" and in the 1970s head of the President's personal political intelligence apparatus Opsus (Operasi Khusus-Special Operations). With him rose his former aide, Brig. Gen. Leonardus Benjamin "Benny" Murdani. Recalled from his post as chargé d'affaires in Pak Chung Hee's Seoul, Murdani took over G-l, and over the next nine years gradually acquired virtual monopoly control of all Indonesia's major official intelligence agencies. Murtopo's specialties were "black" intelligence operations, deployment of agents provocateurs, behind-the-scenes political manipulations, and the sophisticated cultivation of influential politicians, business-men, and academics overseas. One of his most important Opsus creations was the Center for Strategic and International Studies (CSIS), ostensibly a policy-oriented thinktank. The brains of the CSIS were two SinoIndonesians, Harry Tjan Silalahi and Liem Bian Kie, a.k.a. Jusuf Wanandi. (Curiously enough, I had known Liem quite well in 1963-64 when he was still attached to the University of Indonesia's Law Faculty and I was a graduate student doing my dissertation fieldwork.)

The Murtopo-Murdani-Tjan-Liem team was far more sophisticated than its predecessors in its approach to the problem of handling potentially adverse publicity for the Suharto regime. Rather than deploy crude retaliation in Indonesia, they preferred ingenious public relations in the US, Western Europe, and Japan. Accordingly, in October 1975 a large CSIS delegation, including Murtopo, Murdani, and Liem, as well as various technocrats and academics, made a major tour of the US. At this time, Indonesia's image had been severely damaged by the effective bankruptcy of the giant state oil company Pertamina, and by the ten-year long detention without trial of thousands of persons arrested in the aftermath of the October 1, 1965 "coup." The delegation's main objectives appear to have been to limit the damage and to begin creating an effective "Indonesia Lobby" in the US, along lines pioneered by South Korea, Taiwan, and the Dominican Republic. After concluding their official tour on October 23, the delegation came to Ithaca, at their own request, and spent a full day at 
Cornell. In the morning a seminar with faculty and students was held at which Murtopo and Daud Jusuf each gave an address. In the afternoon at an informal gathering at George Kahin's house, an exchange of views on the "Cornell Paper" took place during which Kahin reminded Murdani of the promises made eight years before that key documents needed for further research on the "coup" would be produced. Murdani undertook to see to it personally that they would be transmitted to us in the not too distant future. (Here it should perhaps be noted that by 1975 the authors of the "Cornell Paper" had long since dispersed: while I had joined Kahin in Cornell's Department of Government, Ruth McVey had taken up a position at the School of Oriental and African Studies in London, and Frederick Bunnell had gone to teach at Vassar College.)

On December 7, 1975, little more than a month after the departure of the CSIS delegation, President Suharto launched an amphibious invasion of the newlyindependent former Portuguese colony of East Timor. The initial bloody, botched assault was followed in July 1976 by formal annexation, and in 1977-79, by massive population displacement measures designed to break the resistance of the Fretilin nationalist guerrillas. Between 1975 and 1979, approximately two hundred thousand East Timorese lost their lives to gunfire, famine, and famine-related disease. The war against East Timor had a number of features which significantly changed the relationship between the Indonesian authorities, the CMIP, and important groups in the American political system. In the first place, the Opsus group soon turned out to have been the key architects of Jakarta's East Timor policy. In the eighteen months between the fall of the Caetano dictatorship in Lisbon (April 1974) and November 1976, Murtopo's men attempted to subvert the young independence movement in East Timor by means of propaganda, agents provocateurs, infiltrations of soldiers disguised as locals, as well as public threats and cajolery. They also worked hard behind the scenes to persuade key officials in Portugal's military government to abandon East Timor completely. (A detailed account of Opsus activities in this period is given in Hamish MacDonald's Suharto's Indonesia.) When these "peaceful" tactics failed, another open and full-scale military assault was organized. In the second place, for its own reasons, the US government decided to back Jakarta's aggression. President Ford and Secretary of State Kissinger visited Jakarta the day before the invasion began and made no attempt to head it off. No effort was made to penalize Indonesia for the fact that 90 percent of the military equipment used in the assault came from the US, though this was a clear violation of the terms of the US-Indonesia bilateral arms agreement of 1958. In the face of world opinion, including that of all the West European democracies, America, along with Australia and Japan, defended Indonesia strongly in the United Nations. Thus from the fall of 1975 onwards, the relationship between the CSIS and US officials in the State Department, the Pentagon, and the CIA became ever more intimate, despite widespread criticism of the invasion in the American and international media.

It so happened that in the late fall of 1975, Audrey Kahin, George Kahin's wife, who was then an advanced graduate student in Cornell University's History Department, applied for a research visa to do doctoral research on the history of the Indonesian national revolution in the province of West Sumatra. After inordinate delays, she was finally granted her visa in the spring of 1976; however, she and her husband were told by the officials issuing her the visa in Singapore that Kahin himself 
was on the black list and would not be permitted to accompany her. Later, he was suddenly informed that he would be allowed to join her for "compassionate reasons" for a two-week period. Accordingly, in early May 1976, Kahin took advantage of the temporary suspension of his black list status to come to Jakarta. In the course of the back-and-forth over his admission, it became clear that CSIS (i.e., Opsus) had arrogated to itself some of the role in screening scholars' applicants for visas that earlier had been monopolized by Bakin. Liem Bian Kie in particular made it clear that those who cooperated with CSIS would find visas facilitated and interview opportunities enhanced, while those who failed to do so would be blocked. While research visas continued officially to require only the approval of LIPI and Bakin, Opsus now interposed itself as a crucial intermediary behind the scenes. Liem Bian Kie was fully aware of the importance attached by all Indonesia specialists to having regular access to Indonesia, and therefore understood that control over visas offered CSIS the most effective leverage vis-à-vis the foreign scholarly community.

During his brief stay in Jakarta, Kahin was taken to see both Ali Murtopo himself and CSIS executives Liem Bian Kie and Harry Tjan Silalahi. In the course of these meetings, the CSIS took a new tack. It proposed a formal affiliation between CSIS and the CMIP, and the inauguration of a well-funded joint program which would support research on the Indonesian Revolution by Cornell faculty and graduate students along with several Indonesian scholars. (Choice of this research focus was presumably determined by CSIS's awareness of Audrey Kahin's ongoing research, as well as the fact that Kahin's classic work, Nationalism and Revolution in Indonesia, had largely been devoted to that era.) George Kahin and an unspecified prestigious Indonesian scholar would become coordinators of the project, and, with the help of Murtopo, CSIS would undertake to provide hitherto unavailable documentary and other sources. Kahin politely declined to take up this proposal, on the grounds that the CMIP on principle avoided external affiliations.

Kahin's position during his brief stay in Jakarta was fortuitously made more difficult by the news, conveyed to him personally by an angry Liem Bian Kie, that on May 3 (1976) I had testified before the Subcommittee of International Organizations of the House of Representatives' Committee on International Relations on the subject of abuses of human rights in Indonesia. Since September 1974, this subcommittee, chaired by Representative Donald Fraser, had held a long series of hearings on human rights problems around the world, particularly in countries receiving large quantities of American military assistance. The abuses exposed by the subcommittee led to the enactment in 1975 of the so-called "Fraser Amendment" to the Foreign Assistance Act of 1961, and its further strengthening in 1976. The new legislation required that the President terminate or substantially reduce the security assistance provided to any country engaging in a consistent pattern of gross violations of human rights, and that the Department of State provide the Congress with a detailed annual report on the human rights situation in all countries receiving such security assistance. It was in this context that on April 27, Representative Fraser invited me to testify on conditions in Indonesia and also to "comment on the effect of US aid to the Government of Indonesia." My testimony was critical of the Suharto government's performance, in particular its detention for over ten years, without trial, of at least thirty-four thousand political prisoners. I was also critical of the evasive letter, dated December 16, 1975, issued by Assistant Secretary of State for Congressional Relations Robert 
McCloskey in reply to Fraser's December 4, 1975 letter of enquiry on human rights problems in Indonesia. It is perhaps significant of the changing times that the witness invited to testify for the Indonesian Government was Colonel Benson, who had by then retired from the US Army to become the Washington representative for Pertamina.

Yet if the authorities in Jakarta, like many other authoritarian recipients of US security assistance, were angered by the passage of the Fraser Amendment, they also recognized its force; thus in 1977, 1978, 1979 they released annually approximately ten thousand political prisoners. My own role in these events was extremely minor, but in the eyes of the CSIS and the Indonesian military in general (who were, and are, rather poorly informed about the American political process), I had exploited my credentials as a scholar to help promote a hostile, and effective, political campaign against them.

The main response of the CSIS to the Fraser Amendment was to redouble its efforts to encourage a more favorable image for Indonesia in the eyes of groups and individuals it regarded as influential. On October 18, 1976, Liem Bian Kie wrote to inform George Kahin that, in fulfillment of the previous year's promise, General Murdani was sending a team to Cornell under the leadership of Brig. Gen. Datuk Mulja (a member of Murdani's intelligence staff). The team would be bringing all the documentary materials we had long sought-and more. On October 28, Kahin received a letter from an official in the Jakarta branch office of the Ford Foundation, reporting the rather startling fact that in a conversation with a prominent Indonesian alumnus of Cornell, General Ali Murtopo had volunteered that the "Cornell Paper" was "basically correct," and lacked only some additional facts and documentation.

The Mulja team-which included the Col. Sugondo with whom Benson and I had dealt in April 1972-duly arrived, on November 27. To their evident dismay, Brig. Gen. Nichlany, now Defense Attache in Washington (who had somehow learned of their mission), flew in the same day with two aides. The rival groups stayed in Ithaca for two days, in the course of which Mulja's team turned over twenty heavy (two hundred kilograms!), bound volumes of legal documents, mainly stenographic records of Mahmilub trials. However, key documents we had been asking for since 1967 remained as elusive as ever. We also had an informal seminar at which the main speaker was Col. Sugondo, and a number of reasonably cordial personal conversations. Cassette tapes were made of the seminar and these were later forwarded to Nichlany for transmission to Mulja. In a letter of December 27, 1976 Liem Bian Kie wrote to Kahin expressing pleasure at the outcome of the Mulja mission, adding "I fervently hope that the already existing contact would be developed in a more flourishing cooperation [sic]."

The year 1977 proved a difficult one for the Indonesian government. The most persistent critic of human rights' abuses in Indonesia, Amnesty International, was awarded the Nobel Prize for Peace, and thereby enormously increased its international prestige and credibility. At the same time, the military situation in East Timor deteriorated, necessitating a new style of counterinsurgency campaign aimed at depriving the guerrilla 'fish' of their friendly 'sea.' Aerial destruction of crops in the hinterland and the herding of the population into camps in coastal areas under Indonesian control caused enormous suffering and death. And in spite of a determined news blackout imposed by Jakarta, the outside world began to get some idea of what 
was really going on. Meantime, in Indonesia itself, the end of the year saw increasingly bold and widespread student opposition to Suharto's impending 'unopposed' reelection as President. In February 1978, the Government lashed back, arresting hundreds of student activists, sending soldiers to occupy campuses, and shutting down, for the time being, much of the residually independent press.

It was under these circumstances that Representative Fraser invited me to testify once again before his Subcommittee. On February I5, 1978, I gave my testimony, which was ranged against that of former Ambassador to Indonesia Francis Galbraith, Deputy Assistant Secretary of State Robert Oakley, and Deputy Director of the Defense Security Assistance Agency Erich von Marbod. Much of my testimony this time was taken up with East Timor. The most significant part of it, for present purposes, was unimpeachable evidence (drawn from internal Pentagon documents ${ }^{4}$ ) that during the first six months after the initial Indonesian invasion the US Government (or some part of it) had sent a steady flow of military equipment to Jakarta. The importance of this revelation was that Oakley had told the subcommittee in March 1977 that the US government had been so morally disturbed by the invasion that it had suspended all weapons deliveries during those six months. (In the course of the February 1978 hearings, it transpired that Jakarta had never been informed of this phantom suspension.) In addition, noting that the 1958 Indonesian-American bilateral arms agreement had explicitly forbidden the use of American weapons for purposes of external aggression, I criticized the hypocrisy of the US government's justification for "resuming" weapons deliveries in July 1976 on the grounds that with East Timor's "legal" incorporation into Indonesia in that month, the East Timor problem had become one of "domestic" law and order. ${ }^{5}$ It remains only to add that a sizable group of civil and military officials from the Indonesian Embassy attended these hearings, though not Defense Attache Nichlany himself.

In the meantime, it seems now clear, the CSIS had abandoned its efforts to come to an arrangement with Cornell, and had turned its attention elsewhere. Liem Bian Kie became increasingly visible in Washington and on the West Coast. For a brief time he was a Congressional Fellow attached to Senator Roth's office. In its August 1977 issue, Asian Survey published an article of his entitled "Politico-Security Dimensions of Southeast Asia" (which contained not a single substantive footnote or scholarly citation); in the list of contributors he was identified merely as "Head of the Department of Public Affairs" of CSIS, though by then his role as a key Opsus operative was widely known among Southeast Asian specialists. In February 1979, he emerged as a member of the journal's Editorial Board under his 'Indonesian' name, Jusuf Wanandi. His cultivation of Professor Robert Scalapino, one of Asian Survey's two editors, led, in turn, to a formal affiliation between the CSIS and the University of California at Berkeley's rightwing Institute for East Asian Studies. Thereafter regular semiannual seminars were held at Berkeley and in Indonesia under the joint sponsorship of these institutions to which sympathetic or potentially sympathetic

\footnotetext{
${ }^{4}$ The documents can be found included with my testimony, "US Policy on Human Rights and Military Assistance to Indonesia," in Foreign Assistance Legislation for Fiscal Year 1979, Part 4 (Washington, DC: Government Printing Office, 1978), pp. 27-46.

${ }^{5}$ It should be noted, however, in this context, that the US has never recognized Indonesia's annexation of East Timor as de jure, merely its de facto occupation of the territory.
} 
academics, businessmen, and officials from the US, the UK, Japan, South Korea, and the ASEAN states were invited. Some of these invitees were taken on guided tours of occupied East Timor, and wrote favorable descriptions of their findings on their return. In the late summer of 1980, Liem Bian Kie attempted to extend CSIS influence to the ISSI (Indonesian Studies Summer Institute), a summer program of instruction on the language, culture, history, and politics of Indonesia to which all the main university centers for Indonesian studies in the US contributed. Through Daud Jusuf, a secondechelon CSIS functionary who was then Minister of Education, Liem Bian Kie offered a fully funded fellowship to permit one leading Indonesian academic each year to come to teach within the ISSI framework.

In the interim, a major breach had occurred in the wall of secrecy surrounding Indonesian military activities in East Timor. At the end of 1979 an Australian journalist had managed to smuggle out horrifying pictures of skeletal East Timorese children, some of the numberless victims of a famine raging through the one hundred and fifty 'resettlement camps' where, by Assistant Secretary of State for Far Eastern Affairs Richard Holbrooke's own admission, one hundred thousand East Timorese were concentrated. A New York Times editorial of December 24, 1979 spoke of Indonesia' s "unjust war" and "ruthless military occupation." The Washington Post and the Christian Science Monitor were no less editorially severe. In January 1980, the Jakarta authorities unwisely permitted veteran Times correspondent Henry Kamm to visit the occupied zone, and his report, published on January 28, 1980, was extremely damaging. At that point, I was once again invited to testify before the Congress, this time at a joint hearing held by the Subcommittees on East Asian and Pacific Affairs and on International Organizations. The bulk of the testimony that I gave on February 6 concerned the very grave conditions in East Timor. Among the key points was evidence, drawn from an internal State Department document, ${ }^{6}$ that although US Ambassador Edward Masters knew first hand of the enormous death toll in East Timor as early as September 1978, he had refrained from requesting any US government famine relief for nine months, i.e. until early June 1979. According to the document: "It was not until the spring of 1979 that the Government of Indonesia felt East Timor to be secure enough to permit foreign visitors." In other words, Masters had been unwilling to call for help till the large-scale military Operation Seroja of the spring of 1979 had been completed. Ambassador Masters subsequently wrote an extremely angry letter to George Kahin, with whom he had been acquainted for some years, demanding that Cornell University make him a public apology if I were "not man enough" to do so myself. Kahin showed me this letter, and I replied to Masters that he did not understand the principle of academic freedom if he thought universities were in the business of apologizing for the views of individual faculty members, and that I would be happy to make him an apology if he would produce the documentary evidence to demonstrate that my testimony was mistaken. I heard no further from him. From this point on, the antagonism between myself and many of the State Department officials concerned with Indonesia became quite explicit, though it had been discernible since the time of my first Congressional testimony in 1976.

6 See my "Prepared Testimony on Human Rights in Indonesia and East Timor," in Human Rights in Asia: Noncommunist Countries (Washington,DC: Government Printing Office, 1980), pp. 231-62 and 275-77, also for detailed reference to this document.. 
Two other events of 1980 are worth brief mention since they help explain the bizarre circumstances of my second expulsion from Indonesia in August the following year. In early October I learned of Liem Bian Kie's overtures to the ISSI Board, and of the inclination of some board members to accept them. Concerned that ISSI retain its independence and stay free of penetration, I sent on October 7 a long circular to the ISSI board members, giving them a detailed political biography of Liem Bian Kie, and reminding them that although CSIS attempted to pass itself off as an academic institution, it was in fact an arm of Opsus. Partly as a result of this letter, the board eventually decided to decline the CSIS-Daud Jusuf proposal. Shortly after that, on October 20, at the invitation of the UN General Assembly's Fourth Committee (Decolonization), I testified on Jakarta's military occupation of East Timor and the grave violations of human rights that resulted from it.

Considering the central role that the Murtopo-Murdani-Liem group had played in determining Indonesian policy in East Timor, I had long since assumed that it would be many years, if ever, before I would be permitted to visit Indonesia once again. Thus when Ruth McVey was granted a visa in the fall of 1980 , and was able to conduct a very useful series of interviews with regard to the October I, 1965 "coup," I interpreted this development as an indication that after fifteen years the "Cornell Paper" was no longer a key issue. (She had never said or written anything in public about conditions in East Timor or about other serious violations of human rights in the later 1970s.) Therefore, when in the fall of 1980 the Joint Committee on Southeast Asia of the Social Science Research Council accepted a proposal I had made to sponsor an international conference on polylingualism and Indonesian literature, I suggested that it be held outside Indonesia; alternatively, if it were, for financial and other reasons, to be held in Indonesia, I should not participate. The committee, however, decided that I ought to be a co-chairman, and thus provisional plans were laid to hold the meeting some time in August 1981 either in Singapore or Penang. In the interim, we had obtained the agreement of the Sinar Harapan press-and-publishing conglomerate in Jakarta to act as co-sponsor.

Then suddenly, in April 1981, I received word from a junior official at the Indonesian Embassy in Washington (who had come to Cornell with General Nichlany's retinue in November 1976) that the Indonesian Government would like to have the conference held in Indonesia and that my application for a visa to attend the conference would be favorably regarded. Naturally, I was very surprised, but Nichlany had been fairly cordial at the time of the 1976 visit, and he had since been appointed head of the Indonesian Immigration Service in Jakarta. I was confident that the junior official would never have dared to invite me to apply for a visa unless he had received explicit instructions from his former boss (who, however, had been a Deputy Head of Bakin at the time of my expulsion in 1972). Accordingly, with the feeling that I had nothing to lose, I sent in an application for a short-term visa. In those days, the processing of visa applications, even in routine cases, was a slow process. I was therefore distinctly astonished when my passport, with a visitor's visa stamped in it, was returned to me within forty-eight hours by Federal Express, courtesy of the Indonesian Embassy. Shortly thereafter, in early May, I headed East, and spent much of June and July doing research in Bangkok. Since the conference was due to open on August 19, I decided to enter Indonesia a couple of weeks early, to straighten out any administrative problems that might be in the offing. Accordingly, on Sunday, August 2, 
I flew in to Jakarta, delighted at the prospect of seeing the city and many old friends after an enforced absence of almost ten years. Everything seemed all right until I reached the immigration officers' desks and proffered my passport. At this point a group of plainclothesmen hurried up and ushered me into a side-room. There they informed me that they had been awaiting me for the past two weeks, that my visa was now invalid, and that I must immediately get back on the Thai International plane which was preparing to return to Bangkok. Initially assuming that some bureaucratic mixup had occurred, I asked to be allowed to telephone Nichlany, who was then, as mentioned above, Director General of the Immigration Service. This request was greeted with sardonic smiles-and rejection. I was also prevented from telephoning the cosponsor of the conference and from speaking briefly with the friends who were waiting for me in the arrivals lounge. I was then forcibly escorted onto the plane, which immediately left for Bangkok.

The following day, Monday, August 3, two leading Jakarta dailies printed implicitly critical stories about my deportation. From Bangkok, I telephoned friends of mine who had good contacts with Nichlany and military intelligence; they told me to be patient and await further developments. On Wednesday, August 5, Admiral Sudomo, head of Kopkamtib, stated in reply to reporters' questions that after a meeting with General Ashari (the Indonesian Ambassador in Washington) in Mexico City in June, he had telephoned General Murdani, head of military intelligence in Jakarta, and had got Murdani's clearance for my entry. The same day, and once again on Friday, August 7, Foreign Minister Mochtar Kusumaatmadja told newsmen that the issuance of my visa in Washington had certainly been cleared in advance by the responsible directorate in the Foreign Ministry. Obviously embarrassed by these handwashing statements, the official spokesman for Immigration told the press that same Friday that "all sorts of things could have happened between June and August," and that though I had "made many statements that damaged Indonesia's reputation," he did not wish to foreclose the possibility that I would in the end be permitted to enter Indonesia. That same day, August 7, acting on the telephoned advice of my contacts in Jakarta, I addressed a polite, detailed letter to the Indonesian Ambassador in Bangkok, Lt. Gen. Hasnan Habib, explaining the purpose of the conference I was to help lead, describing its participants and sponsors, and requesting a new visa. To this letter I never received a reply; nor, in the course of several visits to the Embassy, was I ever able to see the Ambassador. Thus when I met with Dr. David Szanton, the executive secretary of the Joint Committee of the SSRC, in Bangkok, on the eve of the conference, we decided that while the SSRC should honor its commitment to pay for the airline tickets of incoming conference participants, it should withdraw its sponsorship of the conference itself. A month or so later, SSRC President Dr. Kenneth Prewitt sent a polite, but strongly worded official letter of protest to Foreign Minister Mochtar Kusumaatmadja. So far as I know, this letter was never answered. In all this, the only comic note was struck by a spokesman for the American Embassy who claimed no knowledge of the incident at the airport, saying that "Anderson has not contacted the Embassy." It was clear that by 1981 there was no possibility of the kind of partial cooperation from the Embassy that had been the one agreeable feature of my first expulsion in 1972.

There are various explanations for why this strange incident occurred, all of them with some elements of plausibility. But on the basis of talks with a number of well- 
informed people during the following months, I came to the tentative conclusion that the Opsus men, in particular General Murdani and Liem Bian Kie-then at the height of their power-were determined to punish me for my testimonies to the Congress and the UN, and perhaps also for my efforts to block the CSIS-ISSI link, but could not do so in the usual way-i.e., by denying me a visa-since I had already been barred for the previous nine and a half years. The only way really to "make it hurt" would be to lure me into thinking I could come by pressing a visa on me and then slamming the door in my face upon arrival in Jakarta. For this scheme to work effectively, knowledge of the real plan would best be concealed from all but a few of the Indonesian officials involved. This scenario helps to explain the really extraordinary press interviews given by Sudomo and Mochtar.

The most recent chapter in this long story, which tends to confirm the MurdaniLiem Bian Kie hypothesis, occurred in February of this year. In April 1984, Audrey Kahin, by then editor of Indonesia (originally founded in the fateful spring of 1966), was awarded a Fulbright Fellowship to do research on the relationship between entrepreneurial groups and the nationalist movement in West Sumatra in the 1930s. Her proposal was quickly approved by LIPI. But after an interminable wait of ten months, she was finally told that Bakin had ordered that she not be given a research visa. ${ }^{7}$ Requests for reconsideration conveyed to General Murdani directly, and via the American Ambassador in Jakarta, had no effect. She and George Kahin did, however, manage to make a flying visit to Indonesia from Singapore in May 1985, taking advantage of new regulations which permit tourists to enter Indonesia for short periods of time without visas. ${ }^{8}$

Two comments on this affair should be noted. First, Audrey Kahin has never written anything or spoken publicly anywhere on the "coup" of October 1, 1965, human rights abuses, or East Timor. If there were any objections to her on the grounds of her editing Indonesia, the authorities should have told LIPI from the start not to approve her proposal. It is difficult not to see in LIPI's approval, the ten-month wait, the abrupt denial of a visa, and the studied ignoring of requests for reconsideration of her case, a pattern of 'punishment' very like that inflicted on me in 1981. It seems likely that the main target of this 'scenario' was George Kahin, who, long on the blacklist himself, was now to be hurt through his wife. Second, it should be noted that in March 1983 Murdani became Commander-in-Chief of the Indonesian Armed Forces and Commander of Kopkamtib, and thus clearly the second most powerful man in Indonesia (Murtopo had died in 1984). It is thus probable that in Audrey Kahin's case his was the decisive voice.

Whether, now that both the Kahins and I have been 'punished,' the regime will eventually relent, remains to be seen. ${ }^{9}$ I personally tend to doubt it. In a couple of months, we will be seeing the twentieth anniversary of the completion of the notorious "Cornell Paper." These twenty years have shown, I think, that between, on the one

\footnotetext{
${ }^{7}$ In December 1981, Audrey, who had received a three-month Social Science Research Council fellowship for research in Indonesia, had been denied even a tourist visa.

8 The Medan airport where they entered was then still without a computer.

${ }^{9}$ In 1991, six years after this article was written, the names of Audrey Kahin and George Kahin were finally taken off the black list.
} 
18 Benedict R. O'G. Anderson

hand, those Western academics who not merely treasure the independence safeguarded by academic freedom, but feel obliged to speak out for truth and justice, as they see them, in their own countries and in those they study, and, on the other hand, the holders of state power who act out of their own political interests and in the name of raison d'etat, there are likely to be irreconcilable conflicts. 